\title{
TRADITIONAL AND ATYPICAL EMPLOYMENT IN LIGHT OF EMPIRICAL DATA
}

\author{
József POÓR ${ }^{1}$, Tímea JUHASZ ${ }^{2}$, Imrich ANTALIK ${ }^{3}$, Imre MADARÁSZ ${ }^{2}$, Ingrid SZABÓ ${ }^{3}$, \\ Gabriella TAMÁSOVA ${ }^{3}$
${ }^{1}$ Szent István University, Faculty of economics and social sciences, H-2100 Gödöllö, Páter Károly u. 1., Hungary. E-mail: Poor.Jozsef@gtk.szie.hu
${ }^{2}$ Szent István University, Faculty of economics and social sciences, H-2100 Gödöllö, Páter Károly u. 1., Hungary. ${ }^{3}$ Selye János Egyetem, SK-9451 Komárno, Bratislavská cesta 3322, Slovak Republic

Accepted 1 November, 2013

\begin{abstract}
Regarding today's employment, flexibility and a high level of adaptability is an individual, as well as a social, necessity. Globalization and the ever increasing market competition have made it necessary for companies to utilize the human resources available to them in an effective way. Atypical employment enables work, or at least its potential availability, even for those who would not be able to work within the framework of traditional employment. In our current publication, we would like to present some results of a questionnaire research which was aimed at the attitudes and expectations regarding atypical employment forms. We are comparing the preferences and stance of our respondents, highlighting possible differences and similarities while using our experience to outline employment improvement suggestions.
\end{abstract}

Keywords: atypical employment, social employment, employee, employer, employment form.

\section{INTRODUCTION}

"Work as an economic concept is a conscious human activity, the aim of which is to create something economically useful and valuable" (Pallas Great Lexicon, Volume 12). Doing work is not equal to employment; it took mankind thousands of years to be able to speak about employment, that is, having other people do relatively regular work. Even after the first forms of employment had come into being, it took further hundred years to look at one of them and consider it so typical or normal that we could regard different forms to be the "atypical" ones.

Basically, employment merely means that somebody gets (that is, employed) another human being to do some work, for which he contributes to their livelihood in the form of monetary or other compensation. This employment can be regular or occasional, and remuneration could be providing home, handing over the excess product or even giving them money.

Modern typical employment assumes a dependency between the employer and the employee where the employed person does not work for "his own benefit" - that is, he does not work for his own profit and at his own risk - and, consequently, he depends on his employer; their relationship is fixed in a written job contract. Both sides are obliged to obey this contract, and it involves another set of relationships on registering the new employee with the authorities (social security, etc.).

Compared to "normal" employment, atypical employment causes a change in the legally regulated relationship between employer and employed. Beáta Nacsa's (1997) categories provide great help to us in navigating between the various new and old employment forms. In her system, an employment form is considered to be atypical if it can fit into more than two of the following four clusters: the length of daily working time, the period of the employment, the place of work and the legal relationship. Based on these clusters, we are going to see just a few types of atypical employment.

The most widely known and the most widespread atypical employment form is part-time employment. However, the validity of international comparison researches is somewhat shadowed by 
the fact that "Western European national labour codes do not usually define part-time jobs; instead, they merely claim that they last shorter per day than full-time work. In France, the legal definition for part-time work is that it is at least a fifth shorter than full-time work. In Denmark, the minimum amount of work in part-time jobs is 15 hours per week, while the top limit is 30 hours per week (Nacsa, 1997, p. 59.). At the same time, Antal Seres (2011) indicates in one of his works that part-time jobs do not necessarily reflect the aims and needs of the employees, but rather, the preferences of the employers. Looking at the entirety of the $27 \mathrm{EU}$ member states (2006), we can see that in most part, the unskilled workers, women and the youngest and oldest workers find employment in this form. We also have to mention that this form is a dynamically expanding one. In Hungary, for example, KSH (2012) claims that "the greatest change brought forth by the economic crisis after 2007 was the r-organization of full- and part-time jobs. Almost 90 thousand fewer people worked in full-time jobs in the second quarter of 2012 than in the same period in 2008, while the growth in part-time jobs in this period was more than $40 \%$ for male and $60 \%$ for female employees."

Another favourite form is flexible-time work, which does not necessarily appear in labour contracts. There are countless variations of this form, the most widespread of which is called "unbound" working hours; this latter could be a combination of working at home, standing "on duty" to be called in any time or even "normal" work.

Job division is a new and special form of employment which is hardly known in Hungary. The novelty of this form comes from the fact that it has no legal predecessor, and the required conditions for this type of employment were all created by the new Hungarian Labour Codes. The idea is that the employer makes a contract or a certain job with not one, but several employees to work in cooperation. Should one of them be hindered in doing their job in any way, the other person may step in line immediately.

Employment may be atypical because of the time period of the job. Employment made for a predefined time period still exists and is widespread among "normal" jobs, but it involves so few people in a given period that labour legislation believes it is not important enough to regulate it, even in a modern society. For this reason, one of the early forms of wage-employments, which appeared in the $19^{\text {th }}$ century and is still present today, is day-labour. This form used to be common among lower classes, and it did not offer many chances to rise from their social stance.

Work contracts made for a pre-defined time period typically contained semi- and unskilled jobs (constructions, less frequently agricultural work), but after the change of the regime in 1989, this form spread into other, higher-qualified jobs as well. KSH mentions that "in 2010, a higher percentage of employers between 15 and 64 worked for a pre-determined time than in previous years (9.6\%). Employers typically apply this form for fresh beginners who are at a disadvantageous negotiating position, which meant that young people were offered this employment form more often than other age groups. A quarter of those between 15 and 24 had such a contract (aged 1519: $45.2 \%, 20-24: 23.7 \%$ ), but the figures were high even among those between 25 and 29 (13.5\%)" (KSH, 2011, pp. 5-6).

The form of occasional work has been the main cause for blacklegging in the last two decades, which is why there have been new regulations every few years to make the situation more manageable and transparent. In 2012, the new Labour Codes of Hungary were created, an even the name suggested that by regulating occasional work, the most important factors will be flexibility and simplicity. The working contract does not have to be written down, but it is possible to make a written one using the sample contract provided by the law. As soon as the work is registered according to the law, the job will be officially created.

The atypical nature of the work may come from the place where the work is done. According to ILO, "regarding employees, the work will be done at home when it is fixed in an agreement made between the employer and the employee (teleworkcontract, outside work, permitted regular work at home). There are no unified figures concerning people working at home even among the older EUmembers: in Austria, Belgium, Denmark, Great Britain and Iceland, the figures go higher than $20 \%$, while the same figure is not even $10 \%$ in Southern Europe - at least according to the definition applied here" (Fazekas and Köllö, 2008, p. 61). At the same time, there are an even lower percentage of people working at home in Hungary. Although the 2011 researches of Sonda Ipsos showed that almost $37 \%$ of the Hungarian 
employees would have liked to work in this form of employment, the 2012 statistics indicated that only about $3 \%$ of all employees did telework, as opposed to the international average of $17 \%$.

Finally, when it comes to more than two people in a job contract, more and more firms are applying atypical forms of employment by contracting out several pursuits (not even just secondary activities) instead of hiring their own employees to do the job (Szabó, 1999). Renting labour today is a functional form of employment only in fields where there is a great number of available workers. The new Labour Codes introduced in Hungary in 2012 regulated all the requirements and duties of the organizations who wish to rent labour. According to these requirements, the job rights are divided between the renting and the borrowing sides. The employee is employed by the renter, who also retains the duties of terminating the job, paying wage, remunerating the expenses of the employee regarding the fulfilment of the job as well as any other requirements of the job itself. Besides legal regulations, the financial and economic crisis also greatly affects the spread of labour renting. Fazekas et al. (2012) point out the crisis when claiming that "labour renting is more and more popular, and in 2011, the amount of rented labourers among firms with more than 5 members rose to $7 \%$." The fact is, however, that even in spite of the frequent new regulations, there are still a lot of open questions regarding this atypical form of employment. It is still not clear, for example, who may receive governmental aid in this employment form, and it is also not sure which side is responsible for paying in certain types of fees after the employee (for example, the rehabilitation contribution to be paid after a change in working abilities).

\section{RESEARCH METHODOLOGY AND RESULT}

We conducted our research this year among the residents of Komárno in Slovakia and Komárom in Hungary. The aim of our research was to map out the current labour market situation in the region, then to come up with suggestions to improve on the employment rates of the population. The research consisted of two parts. Firstly, we conducted in-depth interviews consisting of nine questions; the aim was to see the labour market situation in the border areas. Secondly, in the main part of the research, we issued a questionnaire of 24 questions. The questionnaire consisted of two parts: one asking for personal information and another regarding non-traditional, atypical forms of employment. Both groups contained closed questions, particularly matrix and scaled questions. It took several days to ask all the questions in both cases; 400 questionnaires were filled in eventually, which, in order to retain the representative nature of the research, contained 200 Slovakian and 200 Hungarian ones.

We are starting the presentation of the sample by specification. The questionnaires were filled in at the Komárno and Komárom employment offices. Regarding habitation, $71 \%$ of the Hungarian respondents lived in cities, $29 \%$ in the country, while the same proportion in Slovakia was 48$52 \%$, which means more Slovakians lived in the countryside.

As for genders, $46 \%$ of the respondents were men and $54 \%$ were women; again the two genders were represented almost equally in the samples.

When it came to age, the highest age proportion among the Hungarian respondents was between 30 and 39, while the same category in Slovakia was 25-29.

$27 \%$ of the Hungarian respondents were young entrants to the labour market (between 21 and 24), while the same category on the Slovakian side was barely $19 \%$. As for education, almost $40 \%$ had no secondary degree, meaning they had finished secondary vocational school. The proportion of those with a secondary degree was also equally high in both countries, over $30 \%$. There were no significant differences regarding primary and tertiary degrees among the respondents in either country. In Slovakia, the proportion of people with primary or tertiary degree was $18 \%$ in both cases, and even in Hungary, the number of respondents with a primary degree was only $7 \%$ greater than those with a tertiary one.

Besides personal data, we also put more emphasis on the current positions of the respondents: whether they were working somewhere, they were unemployed or they were in another status. The majority of the respondents, almost $78 \%$, were not working, meaning that they had no job whatsoever. There were no significant differences regarding current employment between the Hungarian and the Slovakian sides (the difference was only 1$2 \%$ ). This was to be expected as the questionnaires were filled in at the employment offices, where mostly unemployed people go. It was interesting for our research, however, that of the remaining 
$22 \%$, only a fraction were doing some form of atypical employment work. The number of people doing traditional work on the Hungarian and Slovakian side was $17 \%$ and $9 \%$ respectively.

The rate of unemployment in 2012 was approximately $18 \%$ in the Komárno region; the situation was somewhat more favourable in Komárom-Esztergom County: 7.2\%. The high level of unemployment on the Slovakian side was partly due to the fact that Nokia, which was located in the Komárom Industrial Park, also employed Slovakian employees through labour conscription firms; after the mass lay-offs, these people became registered unemployed again in the Komárno region.

Based on the questionnaire results, those people who were unemployed for 1-6 months were represented by a notably high percentage in SouthKomárom (around 40\%), but people with lasting unemployment problems were also represented high in North-Komárom (30\%), which shows how serious the situation is in this region. People who had been unemployed between 7 and 12 months were in greater number in Slovakia (almost 20\%) than in Hungary (well under 10\%). The above figures show that even in spite of mass lay-offs, the Hungarian labour market was able to absorb a significant portion of the unemployed, while the same people in Slovakia became lastingly unemployed.

The questionnaire showed that more than threequarters of the respondents have already heard of atypical employment, and only $21 \%$ claimed that they had never heard of these forms. The reason for this may have been that those people with low labour value may not have been in a situation in the labour market where they could have met the employment form in question. This means that they were mostly employed in traditional jobs, or they belonged to the group of the lastingly unemployed who had not worked for more than one year (or perhaps ever).

The majority of the respondents thought that atypical employment did not affect the acquisition of a "normal" job in any way, which meant they had neither negative nor positive opinion on the matter.

The most positive effect is attributed to training organized by labour offices, labour renting and part-time employment. The positive gains come from the fact that the potential employees may acquire knowledge, skills and experience which meet the current demands of the labour market. Employees may even have the chance to get a permanent job contract through labour renting as firms prefer employing workforce they already know and have already trained. Also, part-time job enables employees who are not yet able to work in full time (students, young mothers) to return to 8hour work later when they feel they can now afford it.

Seasonal, occasional and public work has the most unfavourable effect. Seasonal and occasional work is often unofficial, and they provide no previous job reference which could become an asset in later job searches. Public work, in most cases, is a downgrading employment form which does not provide professional development for the individual.

As for the question whether they would accept atypical work, opinions differed according to the type of the employment form. Still, 50-60\% of the respondents would have only accepted such an employment form as a temporary solution. Our conclusion is that even if they received an atypical job, the respondents would still hope that they employer would offer them a job contract for an undetermined amount of time. People see atypical work as a springboard for another job, rather than a long-term solution.

The research seems to justify the assumption that the population of our focus region mostly refuses to work in atypical employment forms, instead insisting on the more traditional ways. They say in almost every case of atypical employment form that it is only a temporary, forced, solution, and they would not accept them if they had got any other chance. Occasional work, which reached almost $79 \%$, received the most negative criticism. It was closely followed by seasonal work $(63.5 \%)$ and public work (60\%). A surprising piece of data was the high antipathy towards labour renting: almost $60 \%$ thought that they would only take such a job out of necessity.

Of all the atypical employment forms, people would choose labour renting as the best alternative, but even so, they hope to be able to return to traditional employment later on. $30-40 \%$ of the respondents also admit that atypical work has its advantages. This advantage is mostly shown regarding part-time job and teleworking, with their $40 \%$ and $47 \%$ respectively. When it comes to the reconciliation of work and private life, more than 
half $(54 \%)$ of the respondents think that more flexible working hours would be more suitable for their needs. Atypical work is the form which favours flexible arrangements the most. The least favourable arrangement for the respondents would be shortened working week and shortened working days; this is partly because these employment forms are not as widespread in our region. 13\% of all people think that neither employment forms we suggested is suitable to them, which we present as evidence that these people actively support traditional employment forms.

While conducting the research, we were trying to reveal how much chance for an economic growth the residents saw in atypical employment. We wanted to know whether the creation of new, nontraditional jobs would assist in climbing out of the current economic crisis as well as offering a solution to the permanently unemployed. Based on the results received, $62 \%$ of the respondents thought that atypical employment would help the economy to climb out of the crisis and $57 \%$ even said it would help the permanently unemployed. The results show that the respondents are not overly optimistic, and they are not sure that this relatively new trend is a secure solution.

However, we managed to talk to several people during the interview, whose answers indicated that they are not really optimistic regarding the current labour market situation in the region. They see no way out of unemployment, and they are distrustful towards the atypical employment forms mentioned in the survey. Many think that this kind of employment allows employers to exploit their workers even more, and they offer no real protection to the employees.

Finally, the main differences of atypical employment between countries typically appear in terms of the forms used. The Hungarians had a more positive attitude towards trainings organized by labour centres and public work than those people living on the other side of the border. 58\% of the Hungarian population thought that training is useful and it helps people to find a new job. A great majority of the respondents also had a positive opinion of public works, and they appreciated the role of the state and the local governments in this matter. On the other hand, most Slovakian respondents found these trainings useless, and they claimed they would have accepted public works only as a last resort.
Regarding labour renting, the Slovakians were also less enthusiastic: only $24 \%$ of them thought that this kind of job would assist them in finding more permanent employment, while $35 \%$ of the Hungarians trusted labour-renting companies more. The Hungarians are more open, and they accept less traditional forms of employment more. With the exception of seasonal and occasional work, more than $20 \%$ of the respondents always thought that they would even accept the given form for a longer period of time. The same figures stayed under $15 \%$ in most cases in North Komárom. In both countries, almost $30 \%$ of the respondents would be willing to take teleworking as a long-term solution; however, this employment form is not typical either in Hungary or in Slovakia.

\section{CONCLUSION}

According to our research results, the respondents in the sample clearly favour traditional employment forms as opposed to atypical ones. More than half of the respondents believe that atypical employment is neutral regarding the chances of getting a normal job, that is, it affects these chances neither negatively nor positively. Also, a great majority of them would only accept an atypical job as a temporary solution: they believe that people only work in atypical jobs out of necessity because they have no other options.

This neutral, often negative attitude from the part of the respondents could be explained saying that they do not consider atypical employment secure and financially stable in the long run.

The government would be well advised to create a detailed legal background which is equally capable of protecting the interests of the employees and the employers. As for the local governments, they should use their employment institutions to create trainings and courses where they would be able to emphasize the advantages of atypical work.

The groups to be targeted should be those with the highest unemployment rate: these people could be young entrants, young mothers and the permanently unemployed. They all represent social strata the employment of which is as much of a challenge in Slovakia as in Hungary; also, these social groups are at some form of a disadvantage by nature.

Comparing the two countries, it can be said that the Hungarians are indeed more open towards atypical 
employment forms. However, the differences are slight, mostly owing to the proximity and the cultural similarities of the two cities.

The biggest differences in opinion were mostly related to trainings and public work organized by employment institutions: the Slovakian population is very pessimistic, while the Hungarians are more optimistic about the above mentioned opportunities. Seasonal and occasional work is the least popular form in both countries; on the other hand, $30 \%$ of the respondents marked teleworking as the form of employment they would accept in the long run as well. However, these forms of employment are the

\section{REFERENCES}

Fazekas, K., Benczúr, P., \& Telegdy Á. (2012). Labour Market Survey (Munkaeröpiaci tükör). 2012, Budapest, OFA, MTA, KTI.

Fazekas, K., \& Köllő, J. (2008). Labour Market Survey (Munkaerőpiaci tükör). 2008, Budapest, MTA, Közgazdaságtudományi Intézet, Országos Foglalkoztatási Közalapítvány.

KSH (2011.) Youth Employment (A fiatalok munkaeröpiaci helyzete. A munkaerö-felmérés alap-, illetve a 2010. IV. negyedévi kiegészitoó felvétele alapján). Budapest, Központi Statisztikai Hivatal, http://www.ksh.hu/docs/hun/xftp/idoszaki/pdf/ifjusa g_munkaero_piac.pdf

KSH (2012). Statistical Mirror (Statisztikai tükör). Munkaeröpiaci folyamatok 2012. I-II. negyedév. VI. évf. 70. szám (2012. szeptember 14.)

Nacsa, B. (1997). Legal Regulation within Atypical Employment (Az atipikus munkaviszonyok jogi szabályozása Nyugat-Európa egyes országaiban). in: Laky Teréz et al. Az atipikus foglalkoztatási formák. Mühelytanulmányok. Budapest, Az EU Integrációs Stratégiai Munkacsoport kiadványa 25. Európai Tükör, 47-69.

Pallas Nagylexikon (1893). Budapest, 1893-1897, Pallas Irodalmi és Nyomdai Rt.

Seres, A, (2011). Trends and Tendencies in Job Sharing (A részmunkaidős foglalkoztatás tendenciái). Közgazdasági Szemle, 58(4), 351-367.

Szabó, K. (1999). Networks in Hyper-Competition (Hálózatok hiperversenyben - Vállalatok szétesése molekuláris egységekre és összekapcsolódásuk). Vezetéstudomány, 30(1), 15-25.

\section{AKNOWLEDGEMENT}

The issue was sponsored by Foundation "Collectively for the Future Workplaces (KJM)". We used our Hungarian article titled „Atypical Employment in the circle of Hungarian and Slovakian employees (in the light of empirical data) published in Hungarian Labor Review to prepare this paper with courtesy of the publisher. 